United States. Even this system, however, is likely to miss the relative importance per unit of exposure of regional seasonal problems (for example, snowmobiling only in northern states and only in winter), and the system includes only two pediatric hospitals. As Weiss et al have pointed out, this may severely bias reporting (HB Weiss et al, presentation to American Public Health Association, San Francisco, October 1993).

This editorial would be incomplete without a comment about the politics of product safety research. In 1969 I testified before the National Commission on Product Safety (NCPS) about the hazards of floor furnaces and the reluctance of manufacturers to acknowledge a problem or to institute corrective actions. ${ }^{8}$ When, shortly after, the NCPS asked me to examine bicycle injuries they tried to get funds for the study from the bicycle manufacturers who, I was told, declined the 'offer'. Given my previous testimony, the manufacturers feared I might be biased in searching for problems.

When my study showed no unique problems with high rise bikes the NCPS appeared no happier about the actual results than the manufacturers had been with what they thought the results might be. Clearly, negative results were not to the commission's interest in showing how they were protecting the public. Thus, an idealistic young researcher learned about the hazards of a different product - the epidemiologic report - in the marketplace.

JULIAN A WALLER Professor Emeritus of Medicine, University of Vermont, Burlington,

125 Holmes Road, $V T, U S A$

South Burlington,
$V T$ 05403, USA

1 Howell TR. Accidents and those bizarre bicycles. Pediatrics 1968; 42: 214 . 2 Waller JA. Bicycle ownership, use and injury patterns among elementary school children. Pediatrics 1971; 47: 1042-50.

3 Pascarella EA. A study of youthful bicycle riders in an urban community. Chapel Hill, NC: Highway Safety Research Center, University of North Carolina, 1971 .

4 Haddon W Jr. On the escape of tigers: an ecologic note. Am $f$ Public Health 1970; 60: 2229-34

5 Waller JA. A survey of snowmobiling in Vermont. Accid Anal Prev 1975; 7: 207-12.

6 Waller JA, Lamborn KR. Snowmobiling: characteristics of owners, patterns of use and injuries. Accid Anal Prev 1975; 7: 213-23.

7 Waller JA, Skelly JM, Davis JH. Emergency department care and hospitalization as predictors of disability. $\mathcal{F}$ Trauma (in press).

8 Waller JA. Testimony about floor furnace burns before National Commission on Product Safety. Hearings of the National Commission on Product Safety. Washington, DC: NCPS, 1969; 3B: 655-8.

\title{
Where have all the programmes gone?
}

The phone in my office rings, it gets passed to me and the conversation goes something like this:

Caller: 'I work for the local health authority and I've just been appointed as accident prevention officer. I've got to do something about the number of children's accidents we have locally. They are a target area in The Health of the Nation strategy, ${ }^{1}$ you know. What can I do to prevent accidents? What are other people like me doing that is effective? Are their programmes published anywhere?'

I stall for time as I know what's coming next. MH: 'What sort of accidents do you have? What are the local data telling you?'

Caller: 'Well, I've tried to find this out but no-one seems to have any data that are much use. The police tell me there are a lot of pedestrian accidents, especially in the summer. We seem to have a couple of deaths in house fires each year and one or two drownings. The hospital data are not much good; it just says that children are admitted with suspected head injuries or poisonings, but it doesn't say why'.

At this stage the conversation goes a bit quiet - except for the sound of my groan. I can refer the caller to the reviews of effective interventions by Pless, ${ }^{2}$ Towner $e t ~ a l,{ }^{3}$ and Munro et al, ${ }^{4}$ but that's about all (and I remember that these reviews highlight the point that many programme papers do not contain enough methodological information to allow others to replicate the work). These enable me to chat about swimming pool fencing, bike helmets, child restraints, child resistant closures, and a couple of other interventions, but to be effective these need legislative support, so the potential role of the health worker is very limited. They also tell me that multiagency working as a technique is effective. To finish the conversation, I tell the caller that he or she is not alone in their lack of useful data (in the UK). He or she rings off, disgruntled.

What I would really like to be able to say is 'There's an excellent new journal called Injury Prevention that is full of information from people in your situation. It will tell you about effective programmes that are being put in place and evaluated around the world. It will give you a host of good ideas, tell you exactly how to carry out the programmes, describe the evaluation techniques used, outline the cost of the programmes, and so on'. But at the moment, I cannot say this.

For those of us for whom the journal has been a longstanding dream, we are delighted by the quality and quantity of the research and epidemiological papers it has been carrying. The leading articles are constantly thought provoking and perceptive. The historical papers bring back memories of the greats. And the citations remind us that we have to cast our reading net much wider - and remind us that there are many journals that we are not reviewing.

But what has been missing from the journal to date is the answer to my caller's questions 'What can I do to prevent accidents? What are other people like me doing that is effective? Are their programmes published anywhere?' We are not receiving papers about intervention programmes, neither successful nor unsuccessful.

This is not a criticism of our present contributors but is a criticism of the people who implement programmes, who actually work to prevent accidents and injuries in their everyday jobs. Is it that no-one is putting programmes that can be shown to be effective in place, or is it that they just do 
not seek to publish the results of their labours? Is it that the only people who write for learned journals are either academics or clinicians? (Or is it that the practitioners do not know about Injury Prevention?)

How do we overcome this shortcoming in the journal, hence making it more valuable and attractive for the practitioner in the local health authority, town council, etc? As the person who has to answer the telephone, I need to know what people are doing in the field - warts and all.

My fellow editor, Susan Gallagher, has come up with a suggestion that would make life easier for would-be contributors (see p 215). She is devising a standard format for short articles, specifically about programmes. These so-called 'vignettes' would not be subject to review and would be aimed at assisting those who are not experienced in writing academic papers by outlining the headings that should be covered. They would encourage communication between practitioners and researchers, and within the practitioner community.

Vignettes or not, we still have to encourage our colleagues whose job it is to prevent accidents and reduce injuries, rather than simply research their numbers and causes, to put pen to paper and share their experiences with everyone else who is still floundering for information on effective, locally based interventions. We also need to encourage our colleagues to send their contributions to Barry Pless as I am sure that he would welcome - and publish - them.

MICHAEL HAYES Associate editor

Child Accident Prevention Trust, 4th Floor, Clerks Court,

18-20 Farringdon Lane,

London ECIR $3 A U$, UK

1 Department of Health. The health of the nation; a strategy for health in England. London: HMSO, 1993.

2 Pless IB. The scientific basis of childhood injury prevention: a review of the medical literature. London: Child Accident Prevention Trust, 1993.

3 Towner E, Doswell T, Jarvis S. Reducing childhood accidents. The effectiveness of health promotion interventions: a literature review. London: Health Education Authority, 1993.

4 Munro J, Coleman P, Nicholl J, et al. Can we prevent accidental injury to adolescents? A systematic review of the evidence. Injury Prevention 1995; 1 : 249-55.

$\begin{array}{llll}\text { Anonymous reviewers 1994-5 (Volume 1) } & & \\ \text { C Acton } & \text { L Davidson } & \text { L McLoughlin } & \text { D Schwartz } \\ \text { P Agran } & \text { W de Jong } & \text { A Mickalide } & \text { S Sheps } \\ \text { J Athey } & \text { R Dershewitz } & \text { J Moller } & \text { G Sherman } \\ \text { L Banco } & \text { G Dougherty } & \text { J Nixon } & \text { J Sibert } \\ \text { M Barrow } & \text { L Duncan } & \text { T Nolan } & \text { Gmith } \\ \text { P Barss } & \text { K Edanius } & \text { L Olson } & \text { L Stallones } \\ \text { D Bass } & \text { S Forjouh } & \text { J Pearn } & \text { R Stanwick } \\ \text { J Bass } & \text { L Francescutti } & \text { W Petridou } & \text { L Stewart } \\ \text { G Beaulne } & \text { S Gallagher } & \text { K Purtscher } & \text { S Teret } \\ \text { D Begg } & \text { R Gofin } & \text { G Regnier } & \text { D Thompson } \\ \text { A Bergman } & \text { B Guyer } & \text { F Rivara } & \text { L Towner } \\ \text { C Berkowitz } & \text { M Hayes } & \text { I Roberts } & \text { A Tursz } \\ \text { P Bijur } & \text { S Jarvis } & \text { M Roberts } & \text { G Vimpani } \\ \text { W Boyle } & \text { M Katcher } & \text { L Robertson } & \text { P Vulcan } \\ \text { R Brison } & \text { R Krishnan } & \text { Y Robitaille } & \text { H Ward } \\ \text { D Chalmers } & \text { J Langley } & \text { C Runyan } & \text { M Widome } \\ \text { K Christoffel } & \text { C Larson } & \text { D Saunders } & \text { T Yamanaka } \\ \text { L Cohen } & \text { S Levene } & \text { L Schelp } & \text { A Zwi } \\ \text { R Cushman } & \text { S Mackenzie } & \end{array}$

